Dirision 37.-Diserses of Oraries.

A fatal case of abscess, with tubercular peritonitis and phle. bitis, is mentioned in Dir. 26.

Division 3S.--Diseases of Uterus.

There was 1 case of retroversion. Under the sub-division "Trmours," those of a non-malignant kind only are included.

Difision 39. - Diseases of Bones and Joints.

2 deaths occurred in patients with disease of the temporal bone, and 1 in a patient with morbus coxarius. The other deaths under this heading arose from phthisis or renal disease.

Division 41. - Discases of Muscles.

In a case of gout and erysipelas there was remarkable relaxation of the extensor tendons of the left arm.

Division 42.-Anomalous Cases.

These comprehend attempts at drowning, intoxication, and a case of profuse salivation.

\section{FATAL CASE OF GOITRE.}

\section{BY A. F. ED ARDS, M.D., Wiveliscombe.}

GoIrre is, in this country, so rarely the cause of death, that $I$ beg to forward the following case for insertion in THE LANCET.

On the 13th of September, 1858, Rhoda H- aged thirteen,-general appearance healthy; complexion florid; blue eyes; had not menstruated, - complained of dyspncea, which I found arose from bronchocele of the whole gland. Prescribed iodide of potassium, internally and externally.

Sept. 24th. - Dyspnoea continued. Ordered leeches to the neck.

28th. - Inability to sleep at night, being roused by a sense of "suffocation," forcing her to "jump up on her hands and knees." Cupping scarificator to both sides of the neck, which was tense and hard, in order to relieve the pressure exercised by the gland, and a small quantity of blood taken.

29th.-Walked about as usual, without much inconvenience Laying her head on a table, and falling asleep, she suddenly awoke, gasped for breath, and became quite insensible; her countenance livid, and the pulse scarcely perceptible at the wrist. She died, apoplectic, in half an hour.

At the inquest held by Mr. Monckton, on the 2nd October, I stated-"I am of opinion that she died of apoplexy from the pressure of the goitre on the internal jugular veins. Sleeping in the recumbent position would tend to accelerate the cause of death in such a case. It is very rare for goitre to cause death; but it does so either where the tumour produces pressure by being very large, or of such rapid growth that the surrounding parts have not time to accommodate themselves to the pressure; which latter was the cause of death in this case." In support of my opinion, I cited the following passages from Boyer's "Traité des Maladies Chirurgicales," vol. vii., p. 68: he says, "Mais quand la tumeur est très grosse, et surtout lorsqu'elle est dure et en quelque sorte squirrheuse, la compression qu'elle exerce sur le larynx, la partie supérieure de la trachêe-artère, les artères carotides, et les veines jugulaires internes, rend la voix faible et rauque, gêne la déglutition, la respiration, produit une apoplexie mortelle, ou fait périr par une suffocation lente à laquelle il est impossible de remédier." Page 70: "Lorsque l'inflammation occupe la totalité de la tu. meur, qu'elle est très intense, et qu'elle présente tous les caracteres du phlegmon, la compression que la goître exerce sur le larynx et la trachée-artère, peut être assez grande pour intercepter la respiration, et faire périr la malade de suffocation." Page 82: "Ainsi l'extirpation de la thyroỉdé est an nombre des opérations que la prudence, la raison, et l'expérience désavouent."

Wiveliscombe, Somerset, Oct. $18 \tilde{3}$.

Cungresses at Vienna.-At Vienna, the meeting of scientific congresses has received considerable discouragement. It was formerly the custom to allow them remuneration for travelling expenses, receptions, \&c. This system is now abolished on account of the late philological meeting, at which several of the members enunciated opinions hostile to those held by some of the Viennese clergy. Vienna, like Edinburgh, seems decorously severe.

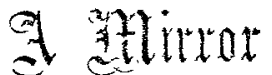

OF THE PRACTICE OF

\section{MEDICINE AND SURGERY \\ IX THE}

HOSPITALS OF LONDON.

Nulla est alia pro certo noseendi vin, nisi quam plurimas et morborum et dissectionum historias, tam aliorum proprias, collectas habere et inter se comparare.-MIongagir. De Sed. et Caus. Alorb. lib. I4. Procmium.

\section{UNIVERSITY COLLEGE HOSPITAL.}

POPLITEAL ANEURISM RECURRING IN THE LEFT HAM, A FEW WEEKS AFTER CURE BY COMPRESSION IN THE RIGHT HAN ; CESSATION OF PULSATION IN FIFTY-SIX. HOURS.

\section{(Under the care of Mr. ErICHSEN.)}

OuR readers will recollect that on a previons occasion (ante, p. 201) we placed upon record an example of popliteal aneurism cured by compression in this hospital, in which pulsation ceased in three days and a half, the patient leaving the hospital, apparently well, on the fourteenth day after admission. The aneurismal tumour was situated in the right ham. Owing to the peculiar nature of his avocation, obliging him to stand on tip-toe to trim and light candelabra in the Queen's Palace, and at the same time to lean forward over tables to effect this, the popliteal spaces became stretched, and thus gave rise to the aneurism. The resumption of his employment, however, produced an aneurism in the left ham, for which he again became a patient, clearly showing that the arterial trunk in both legs, on each occasion of his standing on tip-toe, became elongated more than the natural elasticity of the vessel would permit, rupturing the middle coat, and thus giving rise to the tumours. The same treatment was adopted as on the first occasion, with the cessation of pulsation more speedily than at that timeviz., in fifty-six hours, being fourteen hours later than in $\mathrm{Mr}$. Hilton's patient, whose case was recorded in the same number of this journal as the subject of the present (ante, p. 200). He left the hospital with this second aneurism cured on the tenth day after admission.

The notes of the following case were taken by Mr. John Castenada, the dresser of the patient, who also furnished the notes of the previous report:-

George Whousehold, was admitted into this hospital on August 25th, suffering from popliteal aneurism in the. left leg. $\mathrm{He}$ is of spare habit, five feet ten inches in height, with light hair, fair complexion, cheerful countenance, and his general appearance indicates good health. He is married, and has bealthy children. His father died of renal disease, and his mother of apoplexy. His particular avocation was trimming candelabra, and placing them on tables, which, being broad, obliged him to stand on tip-toe and lean his body forward, putting the popliteal regions on the stretch.

On July 23th, he was discharged from this hospital, cured of the like complaint in the opposite ham.

The history of the present case dates from August 2Ist, when the patient's attention was directed to a throbbing behind the left knee-joint. During the day a circumscribed pain supervened, with stiffness of the joint. The pain and stiffness were relieved, and the limb became easier, after walking about for a few minutes.

Aug. 22nd.-Pulsation and pain, with stiffness, increased. A small swelling was perceptible in the ham, which, on straight. ening the limb, could be distinctly seen to pulsate.

$23 \mathrm{rd}$. - No perceptible increase in the size of the tumour; pain more diffused in character.

24th.--Saw Mr. Erichsen, who told him to come into the hospital again.

25th. - The patient was admitted into the hospital. A tumour about the size of a small walnut was distinguishable near the outer boundary of the popliteal spxce, exhibiting the usual signs of aneurism. Mr. Erichsen was of opinion that it 